\title{
Evaluating the Mechanical Properties of Commonly Used 3d Printed ABS and PLA Polymers with Multi Layered Polymers
}

\author{
Shabana, R.V.Nikhil Santosh, J.Sarojini, K.Arun Vikram, V.V.K.Lakshmi
}

\begin{abstract}
Rapid prototyping is a technology capable of producing physical models in layer by layer directly from CAD model without any tools, dies and fixtures while involving little human intervention. Rapid prototyping can fabricate complex shapes easily as compared with traditional manufacturing. It also helps in early detection and reduction of design errors. Thermoplastics used in this study are ABS and PLA which are easily available and cost effective. This study aim to investigate the mechanical performance of the $3 D$ printed $A B S$ and $P L A$ thermoplastics and comparing them with the sample produced by preparing the multilayer of those themoplastics. An attempt is made to increase the mechanical performance by preparing the samples with multilayer structures using ABS and PLA. Mechanical tests like Tensile test, Compressive test, Flexural strength, Microhardness and surface roughness have been conducted as per the ASTM standards. Microstructures of the samples are acquired with optical microscope. From the results obtained ABS exhibited more flexural strength and higher elongation before breaking. But ABS consists of chemicals when heated to a certain temperature releases organic volatile compounds which are health hazardous. In order to reduce the chemical effect of ABS, a thermoplastic called PLA is used which is produced naturally and is incorporated to decrease $A B S$ content and achieve the properties of $A B S$. In the present work the flexural strength of layered sample is nearer to the ABS. So, inorder to reduce the chemical effects of ABS the layered polymer can be used.
\end{abstract}

Keywords : Acrylonitrile Butadiene Styrene (ABS), Polylactic Acid (PLA), HIPS, PETG, TPU, 3D printing, Additive Manufacturing.

\section{INTRODUCTION}

$3 \mathrm{D}$ printing or additive manufacturing is a manufacturing technology in which objects are produced by adding the material. It is a rapid prototyping process where a actual object can be created from 3D design. A 3D printer uses a CAD (Computer Aided Design) model for rapid prototyping process. The $3 \mathrm{D}$ design is stored in as stereo lithography

Revised Manuscript Received on August 05, 2019

* Correspondence Author

Dr. Shabana*, Mechanical Engineering Department,GITAM University, Visakhapatnam, India.

R.V.Nikhil Santosh, Graduate Engineer TraineeT.V.S.Motors, Hosur, Tamilnadu, India

Dr.J Sarojini, Mechanical Engineering Department,GITAM University, Visakhapatnam, India.

Dr.K.Arun Vikram, Mechanical Engineering Department,GITAM University, Visakhapatnam, India.

VVK Lakshmi, Mechanical Engineering Department,GITAM University, Visakhapatnam, India.
(.STL) format and after that processed to the 3D printer [1] It uses a wide range of materials such as ABS, PLA, HIPS, PETG, TPU and composites as well. 3D printing is one kind of rapidly developing and cost optimized technology which can be used for rapid prototyping. The 3D printer prints the CAD design layer by layer forming an actual 3D object. In the recent years faster and cheaper Additive Manufacturing techniques have been developed which yield to high quality print. Even the polymer materials used for 3D printing are now being produced with a range of properties. [2-6]These developments persistently vary according to the products designed and manufactured as per their applications. 3D printing has applications in many industries such as architecture, automotive, education, medical, business and consumer industries. In general, plastics have low strength compared to metals, they have higher strains lower density and are at failure. But in some cases, Plastics have higher strength per unit weight than metals. Therefore, considering its cost effectiveness and manufacturability with intricate designs, plastics could have more advantages and many applications. [7] The objective of this research is to evaluate the mechanical performance of ABS and PLA and comparing it when they are multilayered. An attempt was made to improve the mechanical properties using the multilayered approach. ABS is a commonly used thermoplastic. It is widely used in FDM printers. ABS has tough, stiff, chemical, moisture and heat resistant properties but its major drawbacks are its non-biodegradability and higher emission of Volatile Organic Compounds (VOC). PLA is a biopolymer prepared from corn, sugarcane. And it has good mechanical properties, low toxicity, and good barrier properties. Its major drawbacks include brittleness and low thermal stability. [8-9]. To reduce the effects of VOC in ABS some multiple layers of PLA were incorporated, and a new specimen was obtained which had only $50 \%$ ABS. The mechanical properties of the multi-layered specimen were tested and compared with ABS and PLA.

\section{EXPERIMENTATION}

All specimens were printed on a DBZ AION 500 rapid prototyping machine shown in Figure 1. Custom printing profile is used to control the slicing/printing software which allows printing in a single specified raster orientation for the entire specimen. Each specimen was printed individually at the center of the printing bed

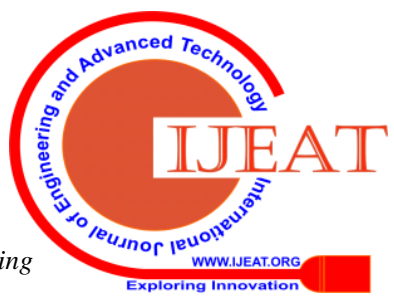


in order to produce uniformity in the samples as much as possible. For the extrusion of the filaments the nozzle temperatures are maintained at which the filament material melts at a particular time. The PLA material has been extruded at $200^{\circ} \mathrm{C}$ and at a speed of $100 \mathrm{~mm} / \mathrm{sec}$ with the heated bed surface at $80^{\circ} \mathrm{C}$. The ABS material got extruded at $229^{\circ} \mathrm{C}$ at a speed of $100 \mathrm{~mm} / \mathrm{sec}$ having the heated bed surface temperature of $80^{\circ} \mathrm{C}$. All specimens were printed with the same generic brand of PLA \& ABS filaments from two 1-kg spools purchased together. Figure 2 shows the raster orientation tested and their identification at an angle of $45^{\circ} \mathrm{C}$.

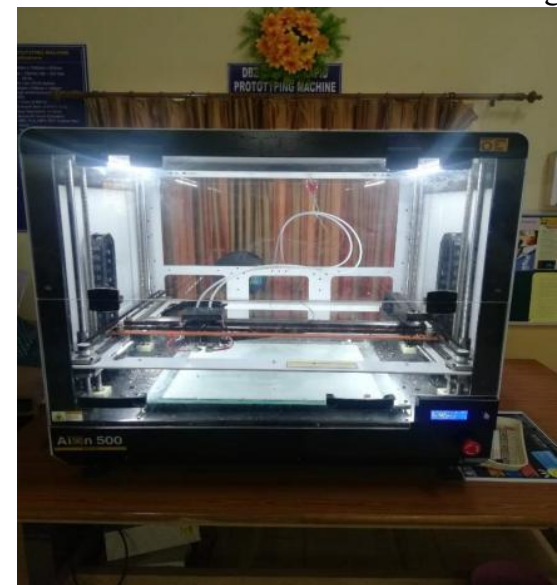

Fig 1. DBZ AION 500 rapid Prototyping

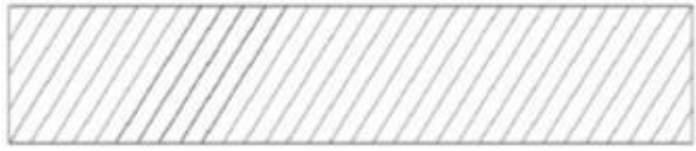

Figure 2: Raster orientation at an angle of $45^{\circ}$

\section{A. TENSILE TEST:}

For finding out the Ultimate Tensile strength of the specimens the samples were prepared as per the ASTM-D638 standard (Figure 3). The tests were conducted using Instron 8801 universal loading machine. The tests were conducted at room temperature. Figure 4 shows the testing setup for tensile testing of the specimen. Three specimens were taken for test for each type of polymer for considering the average as final value. The sample is held between the two load cells and the load is applied for $25 \mathrm{kgf}$ strain gauge load cell.

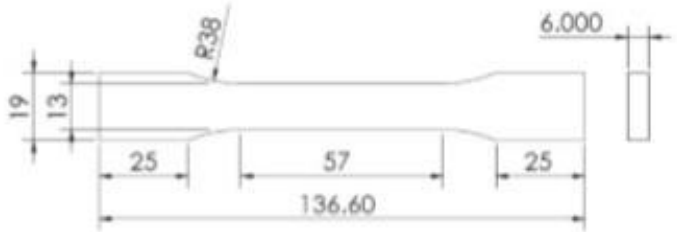

Fig 3. Tensile test specimen dimensions (in mm)

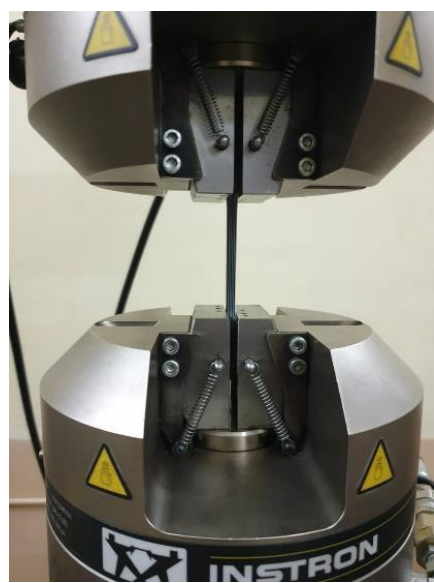

Fig 4. Tensile Test On Instron 8801 Universal Loading Machine

The Instron wedge was displaced at the rate of 3 $\mathrm{mm} / \mathrm{minute}$. The data is obtained from the computer and data acquisition system monitor continuously until the specimen reaches its UTS until it breaks.

\section{B. COMPRESSIVE TEST}

For finding out the compressive strength of the specimens the samples were prepared as per the ASTM-D695 standard as seen in figure 5. The tests were conducted using Instron 8801 universal loading machine. The tests were conducted at room temperature. Figure 6 shows the testing setup for tensile testing machine. Three specimens were taken for test for each

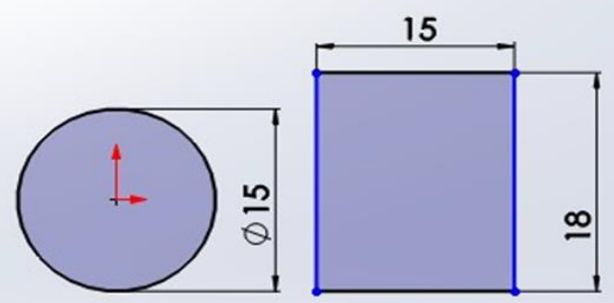

Fig 5. Bending Test Specimen Dimensions (In Mm)

type of polymer for considering the average as final value.

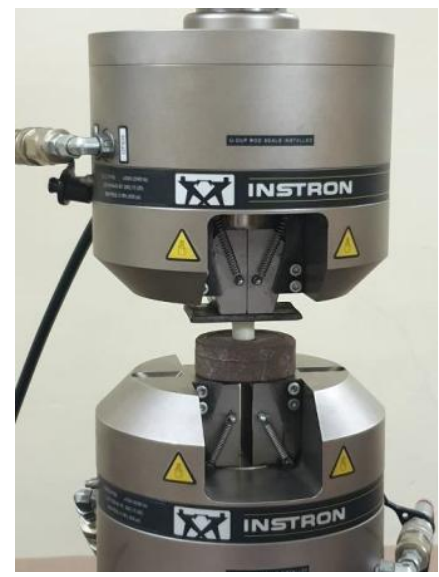

Fig 6 Compression test on Instron 8801 universal loading machine 
The sample is held between the two load cells and the load is applied for $25 \mathrm{kgf}$ strain gauge load cell. The Instron wedge was displaced at the rate of $3 \mathrm{~mm}$ per minute. The computer and data acquisition system monitor continuously until the specimen reaches its Compressive limit.

\section{FLEXURAL TEST}

For finding out the 3-point flexural test of the specimens. The samples were prepared as per the ASTM-D790 [10,11] standard as seen in figure 7 . The tests were conducted using Instron 8801 universal loading machine. The tests were conducted at room temperature. Figure 8 shows the testing setup for flexural testing of the $3 \mathrm{~d}$-printed specimen.

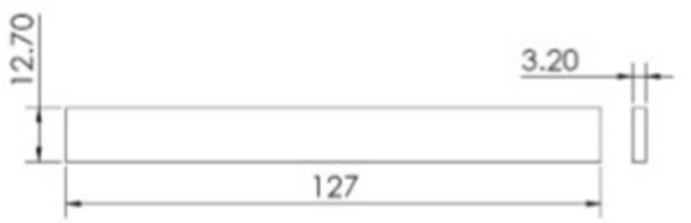

Fig 7. Bending Test Specimen Dimensions (In Mm) Three specimens were taken for test for each type of polymer for considering the average of the three as final value. The sample is held between the two load cells and the load is applied for $25 \mathrm{kgf}$ strain gauge load cell. The Instron wedge was displaced at the rate of $3 \mathrm{~mm}$ per minute. The computer and data acquisition system monitor continuously until the specimen reaches its maximum flexural limit.

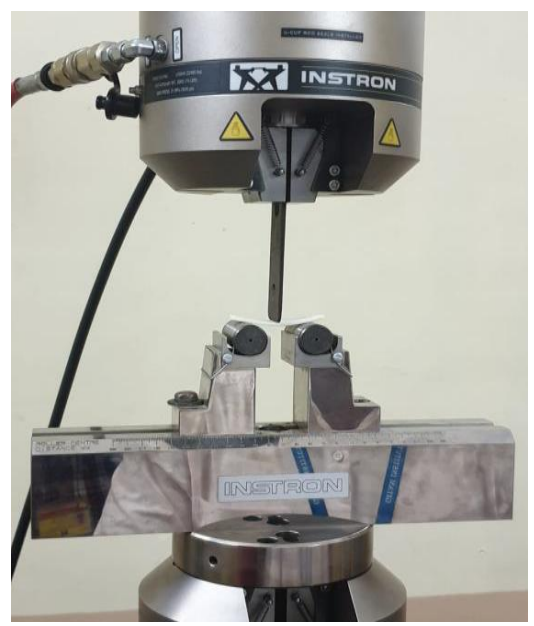

Fig 8. Flexural test set up

\section{MICROHARDNESS TEST}

The samples taken for this test were as shown in the figure 9.

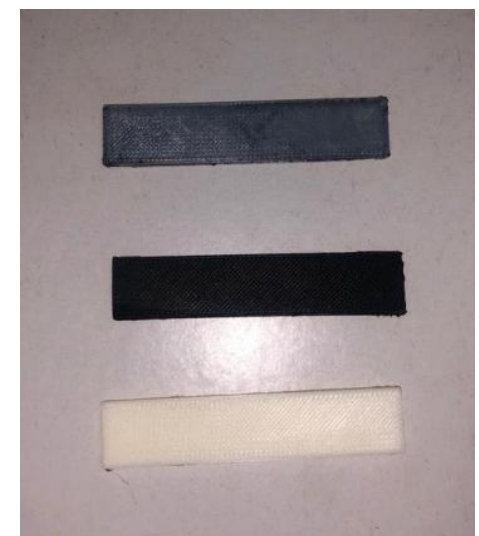

Fig 9. Sample used for the Micro hardness testing Micro hardness measurement was performed as per ASTM Standard at room temperature using Shimadzu HMV-G Series outfitted with a Vickers square pyramidal diamond indenter $\left(136^{\circ}\right)$ as seen in figure 10 . The tests were performed at the load of 50grams at a dwell time of $10 \mathrm{sec}$. the final deformation was measured after the load release using the micrometer eyepiece of the optical microscope. The test was performed in equidistant steps of $100-150 \mu \mathrm{m}$ along the necking region into the cold drawn area. The micro hardness value $(\mathrm{MPa})$. The microhardness values were acquired directly from the digital display.

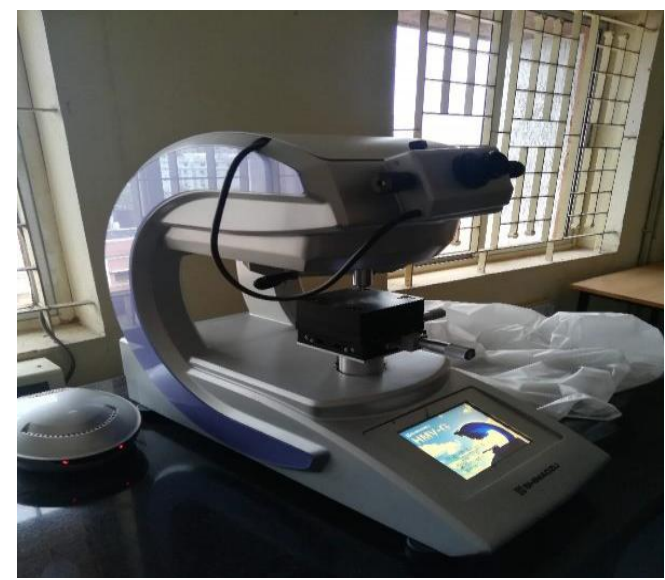

Fig 10. . Microhardness Tester (Shimadzu HMV-G Series)

\section{E. SURFACE ROUGHNESS}

Surface Roughness measurement was performed as per ASTM Standard at room temperature using Mitutoyo Portable Surface Roughness Measurement as shown in figure 11. The probe moves forward and backward on the surface of the specimens. The equipment calculates $(\mathrm{Ra})$ and $(\mathrm{Rz})$ an arithmetical mean roughness and mean roughness depth values. 


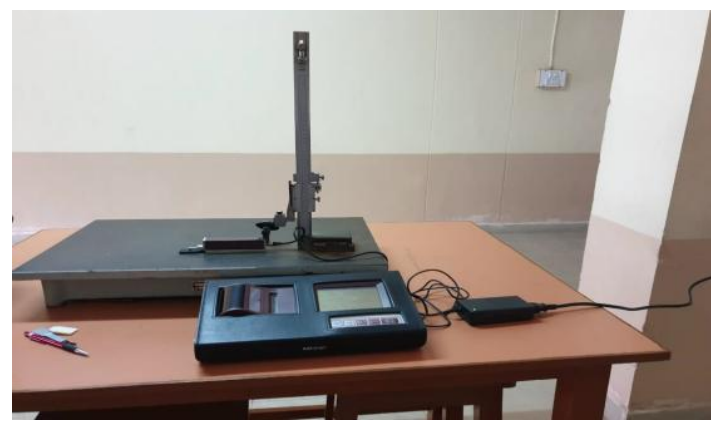

Fig 11. Mitutoyo Portable Surface Roughness Measurement

\section{F. MICROSTRUCTURES}

Microstructure of three materials was taken from the Leica DM ILM Inverted Microscope. Microstructures were taken at room temperature as shown in figure 12 This Microscope acquires microstructure from $10 \mu \mathrm{m}$ - $100 \mu \mathrm{m}$. High-performance optics give crisp, clear image resolution and contrast in incident light, brightfield, polarization contrast, and fluorescence. It is designed to handle large samples of objects by saving time while performing testing of large sample as seen in figure 12 .

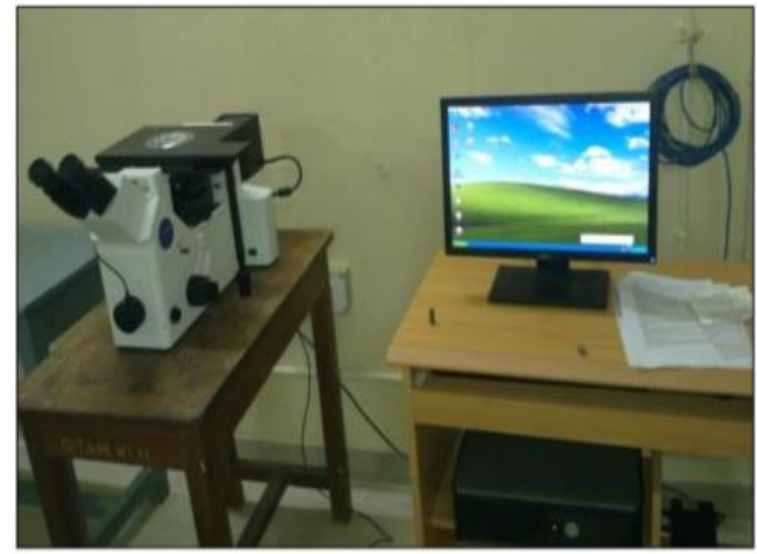

Fig 12. Optical Microscope

\section{RESULTS AND DISCUSSIONS}

The Ultimate tensile strength values are compared in the table 1

Table-1: Comparison of Ultimate tensile strength between the ABS, PLA and Layered ABS and PLA material

\begin{tabular}{|c|c|c|c|c|}
\hline $\begin{array}{c}\text { Specimen } \\
\text { Label }\end{array}$ & $\begin{array}{c}\text { Maximum } \\
\text { load } \\
(\mathbf{K N})\end{array}$ & $\begin{array}{c}\text { Breaking } \\
\text { load } \\
\mathbf{( k N )}\end{array}$ & $\begin{array}{c}\text { Load } \\
\text { at 2\% } \\
\text { strain } \\
\mathbf{( k N )}\end{array}$ & $\begin{array}{c}\text { Ultimate } \\
\text { Tensile } \\
\text { Strength } \\
\text { (MPa) }\end{array}$ \\
\hline ABS & 0.67 & 0.44 & 0.44 & 13.42 \\
\hline PLA & 1.02 & 0.98 & 0.71 & 20.34 \\
\hline $\begin{array}{c}\text { Sandwich } \\
\text { of ABS } \\
\text { and PLA }\end{array}$ & 0.72 & 0.5 & 0.53 & 14.46 \\
\hline
\end{tabular}

From the results obtained during the Tensile test it is observed that PLA has the higher value than the other two thermoplastics. The compression strength values are compared in the table 2

Table-2. Comparison of Compression strength between the
ABS, PLA and Layered ABS and PLA material

\begin{tabular}{|c|c|c|c|}
\hline $\begin{array}{c}\text { Specimen } \\
\text { label }\end{array}$ & $\begin{array}{c}\text { Maximum } \\
\text { Load } \\
\text { (N) }\end{array}$ & $\begin{array}{c}\text { Compressive } \\
\text { Strength } \\
\text { (MPa) }\end{array}$ & $\begin{array}{c}\text { Compressive } \\
\text { strain at } \\
\text { Maximum } \\
\text { Comp. load } \\
\text { (mm/mm) }\end{array}$ \\
\hline ABS & 3103.28 & 20.16 & 0.36544 \\
\hline PLA & 5222.39 & 33.93 & 0.42582 \\
\hline $\begin{array}{c}\text { Sandwich } \\
\text { of PLA and } \\
\text { ABS }\end{array}$ & 3203.44 & 20.81 & 0.4278 \\
\hline
\end{tabular}

It is observed from the table 2 that the compressive strength of the PLA and Sandwich are same. The Flexural strength values are compared in the following table 3

Table 3: Comparison of Flexural strength between the ABS, PLA and Layered ABS and PLA material

\begin{tabular}{|c|c|c|c|c|}
\hline $\begin{array}{c}\text { Specimen } \\
\text { label }\end{array}$ & $\begin{array}{c}\text { Maximu } \\
\text { m load } \\
\mathbf{( N )}\end{array}$ & $\begin{array}{c}\text { Maxim } \\
\mathbf{u m} \\
\text { Stress } \\
\text { (MPa) }\end{array}$ & $\begin{array}{c}\text { Flexure } \\
\text { strain at } \\
\text { Maximu } \\
\mathbf{m} \text { Flexure } \\
\text { stress }\end{array}$ & $\begin{array}{c}\text { Flexure } \\
\text { extension at } \\
\text { Maximum } \\
\text { Flexure load } \\
\text { (mm) }\end{array}$ \\
\hline ABS & 84.98737 & 47.22 & 0.0334 & 8.87735 \\
\hline PLA & 32.17682 & 17.88 & 0.06392 & 4.63891 \\
\hline $\begin{array}{c}\text { Sandwich } \\
\text { of PLA and } \\
\text { ABS }\end{array}$ & 34.34876 & 19.08 & 0.06859 & 9.52694 \\
\hline
\end{tabular}

From the above table 3 the Sandwich sample showed maximum flexural strength. The micro hardness values are compared in the following table 4

Table 4: Comparison of micro hardness between the ABS, PLA and Layered ABS and PLA material

\begin{tabular}{|c|c|}
\hline Specimen Label & $\begin{array}{c}\text { Vickers } \\
\text { Hardness }\end{array}$ \\
\hline ABS & 129.6 \\
\hline PLA & 125.33 \\
\hline $\begin{array}{c}\text { Sandwich of ABS and } \\
\text { PLA }\end{array}$ & 125.6 \\
\hline
\end{tabular}

The micro hardness values when compared showed almost similar values.

The Surface Roughness Values Are Compared In The Following Table 5

\begin{tabular}{|c|c|}
\hline Specimen Label & $\mathbf{R}_{\mathbf{A}}(\boldsymbol{\mu} \mathbf{m})$ \\
\hline ABS & 9.40 \\
\hline PLA & 6.73 \\
\hline Sandwich of ABS and PLA & 9.59 \\
\hline
\end{tabular}

The surface roughness of ABS and Sandwich are same where as PLA has less value. The microstructures shown in figures $11,12,13$ showed homogenous distribution of the particles and are uniform in structure. 


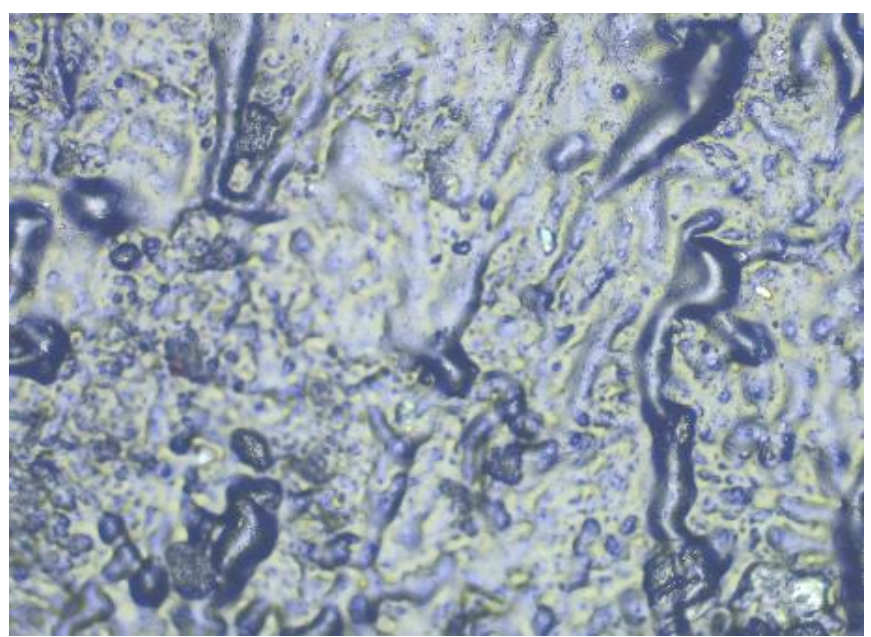

Fig 11. Microstructure of ABS

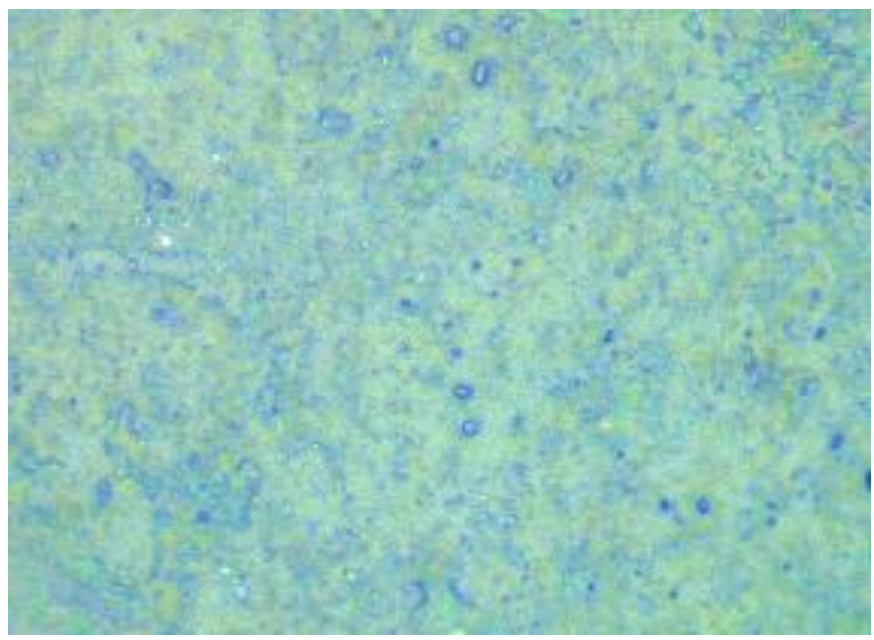

Fig 12. Microstructure of PLA

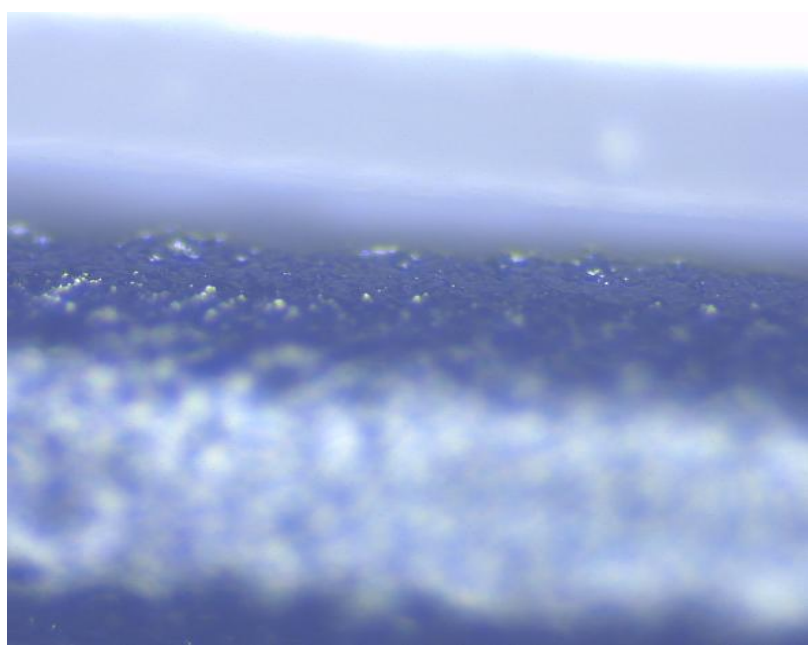

Fig 13. Microstructure of Sandwich structure

\section{CONCLUSIONS}

1. The Ultimate Tensile Strength (UTS) value of PLA is found out to be superior to ABS and multilayer specimens.

2. The compressive strength of PLA and Sandwich was equal. ABS has minimum value.

3. The maximum flexural stress was observed in Sandwich.

4. Micro hardness of all the three specimens was almost equal.
5. Surface Roughness of Sandwich and ABS were found to be similar but PLA exhibited minimum surface roughness.

6. The microstructures of all the three samples are of uniform structure.

7. From the results obtained Sandwich of ABS and PLA exhibited more flexural strength and higher elongation before breaking. This layered Thermoplastic can be used where there is flexural strength requirement. Under such applications the usage of ABS can be minimized and be replaced with the sandwich plastic inorder to reduce the environmental effects.

\section{ACKNOWLEDGMENT}

The authors would like to thank GITAM Deemed to be University for proving the equipment for doing all the tests within the campus.

\section{REFERENCES}

1. John Ryan C. Dizon, Alejandro H. Espera Jr., Qiyi Chen, Rigoberto C. Advincula "Mechanical characterization of 3D-printed polymers".

2. B. Berman, Bus. Horiz " 3 -D printing: the new industrial revolution), 55 (2012)155-162.H. Poor, An Introduction to Signal Detection and Estimation. New York: Springer-Verlag, 1985, ch. 4

3. S. Tranchard, V. Rojas, "Manufacturing Our 3D Future", 5 May 2015. [Online],2015

4. Form labs, "3D Printing with Desktop Stereolithography An Introduction for Professional Users", White Paper, 2015.

5. W. Gao, "The Status, Challenges, and Future of Additive Manufacturing in Engineering", vol. 69, 2015, pp. 65-89.

6. X. Wang, M. Jiang, Z. Zhou, J. Gou, D. Hui, "3D printing of polymer matrix composites: a review and prospective, Computer Aided Design Composition". Part B110 (2017) 442-458.

7. D. Kazmer, in: M. Kutz, "Three-Dimensional Printing of Plastics, Applied Plastics Engineering Handbook - Processing, Materials, and Applications", A Volume in Plastics Design Library, 2nd ed., 2017.

8. Charungkit Chaikeaw and Kawee Srikulkit, "Preparation and Properties of Poly(lactic Acid)/PLA-g-ABS Blends, Fibers and Polymers 2018, Vol.19, No.10, 2016-2022

9. Szymon Wojtyła, Piotr Klama, and Tomasz Baran, "Is 3D printing safe? Analysis of the thermal treatment of thermoplastics: ABS, PLA, PET, and nylon".

10. Taufik, Mohammad; Jain, Prashant K. "Role of build orientation in layered manufacturing: a review". International Journal of Manufacturing Technology and Management. 27 (1/2/3).

11. Shabana, R.V.Nikhil Santosh, "Studying the Mechanical properties of Aluminum 6063 reinforced with Silicon Carbide and Mica", International Journal of Engineering and Advanced Technology (IJEAT) ISSN: 2249 8958, Volume-8, Issue-2S2, January 2019.

\section{AUTHORS PROFILE}

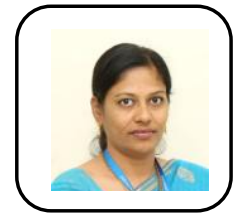

Dr. Shabana, Ph.D., has a teaching experience of 13years. Her research interest are in field of coatings, metal matrix composites and 3D printing. The author has publications in reputed journals in the above fields. She has co-authored an Engineering text book "Electrical and Mechanical Technology" published by S. Chanad.

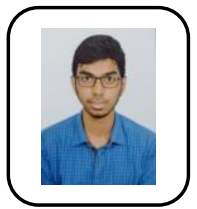

R V Nikhil Santhosh has completed graduation at Gitam University in the department of mechanical engineering. He is currently working as a graduate engineer trainee at TVS motors, Hosur Tamil Nadu.

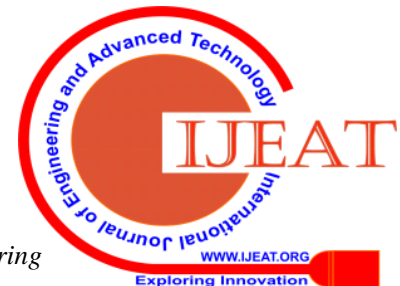




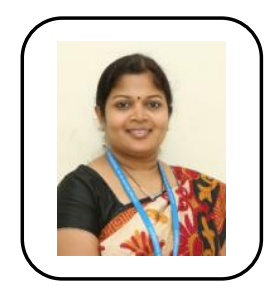

Dr J Sarojini, Ph.D. has 18 years of teaching experience. Her research areas include discrete optimization, metal matrix composites, extrusion. She authored four books in her reach areas. The author is an Associate Member of Institution of Engineers. She has completed a DST funded project.

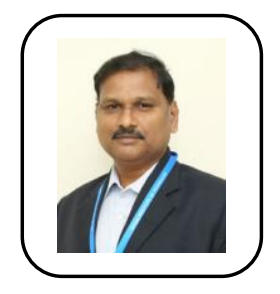

Dr K. Arun Vikram, Ph.D. has 13 years of teaching experience. Her research areas include multi-axis machining, optimization, and eco-friendly machining. He authored three engineering textbooks and various research journal papers in his research areas. The author is a Life Member of Institution of Engineers. He has an DST funded project.

ongoing

Ms V V K Lakshmi (MS) has 7 years of industry and 9 years of teaching experience. Her research areas include Soft computing, optimization, machining and Metal matrix composites. She is an Associate Member of Institution of Engineers and member of Computer society of India. 